\title{
Characterization of Vibrio viscosus and Vibrio wodanis isolated at different geographical locations: a proposal for reclassification of Vibrio viscosus as Moritella viscosa comb. nov.
}

\author{
Eva Benediktsdóttir, ${ }^{1}$ Linda Verdonck, ${ }^{2}$ Cathrin Spröer, ${ }^{3}$ \\ Sigurður Helgason ${ }^{4}$ and Jean Swings ${ }^{2}$
}

Author for correspondence: Eva Benediktsdóttir. Tel: +354 56884 47. Fax: +354 5688457. e-mail: eben@rhi.hi.is

1 Institute of Biology, Microbiology Laboratory, University of Iceland, Ármúli 1A, IS-108 Reykjavík, Iceland

2 Laboratory of Microbiology, University of Ghent, Ledeganckstraat 35, B-9000 Ghent, Belgium

3 Deutsche Sammlung von Mikroorganismen und Zellkulturen $\mathrm{GmbH}$, Mascheroder Weg $1 b$, D-38124 Braunschweig, Germany

4 Institute for Experimental Pathology, Fish Disease Laboratory, Keldur, University of Iceland, IS-112 Reykjavík, Iceland

\begin{abstract}
Vibrio viscosus and Vibrio wodanis are recently described species of psychrotropic bacteria that have been found associated with a disease called ' winter ulcer', affecting salmonid fish reared in saline water in Norway, Iceland and recently in Scotland. $V$. viscosus and $\boldsymbol{V}$. wodanis strains initially isolated from fish in Iceland and Norway were subjected to characterization using biochemical tests, SDS-PAGE of whole-cell proteins and a novel DNA fingerprinting method, amplified fragment length polymorphism (AFLP). The $V$. viscosus strains isolated from diseased fish grouped into homogeneous subgroups according to geographical origin and challenge experiments revealed that representatives of these groups are virulent. The results revealed that the $V$. wodanis strains are heterogeneous genotypically and phenotypically. Sequencing of almost complete $16 \mathrm{~S}$ rRNA genes of $v$. viscosus and $V$. wodanis revealed that $V$. viscosus showed a $99 \cdot 1 \%$ sequence similarity to Moritella marina and $V$. wodanis showed a $98.8 \%$ sequence similarity to Vibrio logei CIP 103204. A reclassification of Vibrio viscosus as Moritella viscosa comb. nov. is proposed.
\end{abstract}

Keywords: Moritella, Vibrio, psychrophiles, fish pathogens

\section{INTRODUCTION}

Skin ulceration is one of the most frequently recorded disease conditions in farmed fish and can be produced by microbiological as well as mechanical means. A disease called 'winter ulcer', which affects salmonid fish reared at cold temperatures, is characterized by shallow skin lesions and often by diffuse or petechial haemorrhaging in internal organs. Winter ulcer has been observed for many years in Norway (Lunder, 1992; Lunder et al., 1995) and Iceland (Benediktsdóttir et al., 1991, 1998) and recently in Scotland (Bruno et al., 1998; Laidler et al., 1999). Two groups of psychrotropic vibrio bacteria are most often isolated from the lesions or the internal organs, either one of them or a mixed culture of both species. The two groups have

The EMBL accession numbers for the $16 \mathrm{~S}$ rDNA sequences of Moritella viscosa and Vibrio wodanis are Y17574 and Y17575, respectively. recently been described as two new species, Vibrio viscosus and Vibrio wodanis (Lunder et al., 2000). Two strains of $V$. viscosus have been tested for pathogenicity in Norway and Iceland, respectively, and both were shown to be pathogenic for Atlantic salmon parr, but strains of $V$. wodanis that have been tested for pathogenicity have not been shown to be virulent to Atlantic salmon (Lunder et al., 1995; Benediktsdóttir et al., 1998).

The present work is based on a strain collection isolated mostly from fish suffering from winter ulcer in Iceland and Norway. Two fingerprinting techniques were used to compare strains of $V$. viscosus and $V$. wodanis isolates from different geographical locations: SDS-PAGE of whole-cell soluble proteins and amplified fragment length polymorphism (AFLP) (Vos et al., 1995; Janssen et al., 1996), in addition to biochemical and physiological tests. For characterization and epidemiological purposes, the AFLP technique has been used to differentiate strains of bacteria, including Aeromonas (Huys et al., 1996), Vibrio vul- 
nificus (Arias et al., 1997) and Bacillus (Keim et al., 1997). The AFLP technique depends on the selective amplification of restriction fragments of whole chromosomal DNA and discriminates between bacterial strains below the species level. SDS-PAGE depends on the products of the whole chromosome and groups strains to species and sometimes subspecies levels. Both methods have been proposed to provide a reliable way to measure genomic relatedness that would be comparable to DNA-DNA hybridization (Kersters, 1985; Huys et al., 1996).

DNA hybridization has shown that the closest known relatives to $V$. viscosus and $V$. wodanis are Vibrio marinus and Vibrio logei, respectively (Lunder et al., 2000). Sequencing of the 16S rRNA of $V$. marinus (Kita-Tsukamoto et al., 1993; Gauthier et al., 1995) has confirmed earlier studies based on 5S rRNA sequencing (MacDonell \& Colwell, 1985) and DNADNA hybridization (Steven, 1990) that indicated that $V$. marinus does not belong to the Vibrio genus. Accordingly, a new genus, Moritella, has been proposed to accommodate this species (Urakawa et al., 1998). Hereafter this species will be referred to as Moritella marina.

In this study, genotypic and phenotypic variability of strains of $V$. viscosus and $V$. wodanis isolated at different geographic locations were investigated and the sequences of almost complete 16S rRNA genes of $V$. viscosus and $V$. wodanis were determined.

\section{METHODS}

Bacterial strains. A total of 68 fish strains and 3 reference strains were included in the study. Of the fish strains, 37 were isolated in Iceland and 29 in Norway, mostly from diseased Atlantic salmon. The reference strains $M$. marina NCIMB $1144^{\mathrm{T}}$ (ATCC $15381^{\mathrm{T}}$ ), V. logei NCIMB 1143 (ATCC 15382) and $V$. logei NCIMB $2252^{\mathrm{T}}$ (ATCC $29985^{\mathrm{T}}$ ) were obtained from the National Collections of Industrial and Marine Bacteria, Aberdeen, UK. Strains 95/373-2988, 95/373-2989, 95/378, 95/403, 95/449, 95/453, 95/371, 95/461 and 95/880 were kindly supplied by S. Høie and strains NVI $88 / 478^{\mathrm{T}}$ and NVI $88 / 441^{\mathrm{T}}$ by E. Myhr, both at the National Veterinary Institute in Oslo, Norway. Strains 94/1793-1, 94/1793-2, 95/240, 95/313, 95/325 and 95/326, which originally came from the National Veterinary Institute in Oslo, were kindly given by K. Pedersen, Royal Veterinary and Agricultural University, Copenhagen, Denmark. Strains 138/94, 153/94, 157/94, 270/95, 271/95, 287/95, 288/95, 289/95, 290/95, 291/95, 292/95 and 293/95 were kindly supplied by E. Greger, ALPharma, Bellevue, WA, USA. Strains labelled K were isolated at the Fish Disease Laboratory, Keldur, Reykjavik, Iceland; strains labelled F were isolated at the Biology Institute, Reykjavik, Iceland. A list of strains included in this study and their origin is presented in Table 1.

The strains were maintained on Marine agar 2216 (Difco) at $4{ }^{\circ} \mathrm{C}$ and reinoculated every 1 or 2 months. Long-term storage was at $-80^{\circ} \mathrm{C}$ in Marine broth 2216 supplemented with $10 \%$ glycerol.

16S rDNA sequencing. Two strains were used, $V$. viscosus $88 / 478^{\mathrm{T}}$ and $V$. wodanis $88 / 441^{\mathrm{T}}$. Extraction of genomic
DNA and amplification of the 16S rDNA was carried out as described by Rainey et al. (1992). PCR products were purified using the Prep-A-Gene kit and sequenced directly using the Taq DyeDeoxy Terminator Cycle Sequencing Kit (Applied Biosystems). Purified sequence reactions were electrophoresed on a $6 \%(\mathrm{w} / \mathrm{w})$ polyacrylamide gel for $12 \mathrm{~h}$ using an Applied Biosystems model 373A Automated DNA Sequencer.

Sequences were manually aligned with published sequences of the $\gamma$-proteobacteria included in the Ribosomal Database Project (Maidak et al., 1997). Pairwise evolutionary distances were computed using the correction of Jukes \& Cantor (1969). Phylogenetic analyses were carried out as described by DeSoete (1983). Bootstrap values, based on the analyses of 1000 trees of 796 polymorphic sites, were calculated using the programs NJFIND and NJBOOT.

\section{AFLP}

Extraction of genomic DNA. Cells were harvested from Marine agar and washed in $500 \mu \mathrm{l}$ RS buffer $(150 \mathrm{mM} \mathrm{NaCl}, 10 \mathrm{mM}$ EDTA, $\mathrm{pH}$ 8.0). After centrifugation the cells were resuspended in $100 \mu \mathrm{l}$ TE buffer $(10 \mathrm{mM}$ Tris $/ \mathrm{HCl}, 1 \mathrm{mM}$ EDTA, pH 7.6) and $15 \mu \mathrm{RNase}\left(10 \mathrm{mg} \mathrm{m}^{-1}\right)$ was added to the suspensions. Lysis of the cells using Sarkosyl/guanidium thiocyanate (Sigma) and further extraction of genomic DNA was as described by Pitcher et al. (1989). The DNA was finally dissolved in $100 \mu \mathrm{l}$ TE buffer $(10 \mathrm{mM}$ Tris $/ \mathrm{HCl}$, $0.1 \mathrm{mM}$ EDTA, pH 8.0). The DNA concentration was determined by measuring $A_{260}$ on a spectrophotometer (1 $\mathrm{OD}_{260}$ unit $=50 \mu \mathrm{g}$ DNA ml ${ }^{-1}$ ). The integrity of the DNA was checked by electrophoresis in a submerged horizontal agarose gel $(0 \cdot 8-1 \cdot 0 \%, \mathrm{w} / \mathrm{v})$ using an electrophoresis buffer (40 mM Tris/acetate, $1 \mathrm{mM}$ EDTA, pH 8.0) containing $0.5 \mu \mathrm{g}$ ethidium bromide $\mathrm{ml}^{-1}$. DNA preparations were stored at $-20{ }^{\circ} \mathrm{C}$.

Oligonucleotide adaptors and primers. The sequences of the HindIII and TaqI adaptors and primers used in this study are given in detail by Janssen et al. (1996).

Template preparation. Template preparation was as described by Vos et al. (1995) and Janssen et al. (1996). Thus, in this study, $1 \mu \mathrm{g}$ DNA was digested with 10 units each of HindIII and TaqI in a final volume of $30 \mu \mathrm{l}$. Adaptors were added to a final concentration of 0.04 and $0.4 \mu \mathrm{M}$ for HindIII and TaqI adaptors, respectively, and ligated to the restriction fragments using T4 ligase. The DNA was subsequently precipitated with $1.25 \mathrm{M}$ ammonium acetate and $50 \%(\mathrm{v} / \mathrm{v})$ 2-propanol. Template DNAs were stored at $-20{ }^{\circ} \mathrm{C}$.

AFLP reactions. AFLP reactions employed two oligonucleotide primers: H01, corresponding to the HindIII ends, and T01, corresponding to the TaqI ends. The HindIII primer was radioactively end-labelled using $\left[\gamma^{3}{ }^{33} \mathrm{P}\right]$ ATP and T4 polynucleotide kinase (Vos et al., 1995). Selective amplification and PCR reactions were performed on a PE 9600 thermocycler (Perkin Elmer) as described by Janssen et al. (1996).

Gel analysis. Prior to gel loading and electrophoresis, mixtures were heated for $3 \mathrm{~min}$ at $95^{\circ} \mathrm{C}$ and then rapidly cooled on ice to prevent nucleic acids from reannealing. Each sample $(1 \cdot 8-2.0 \mu \mathrm{l})$ was loaded on a $5 \%$ denaturing sequencing polyacrylamide gel (obtained as premixed SequaGel solutions from National Diagnostics). To $100 \mathrm{ml}$ casting solution, $0.8 \mathrm{ml} 10 \%$ ammonium persulfate and $40 \mu \mathrm{l}$ TEMED were added and gels were cast using a SequiGen $38 \times 50 \mathrm{~cm}$ gel apparatus (Bio-Rad). TBE (100 mM Tris/ 
Table 1. Bacterial strains used in the study and their origin

\begin{tabular}{|c|c|c|c|}
\hline Species & Designation & Origin & Place of isolation \\
\hline \multirow[t]{7}{*}{$\begin{array}{l}\text { V. viscosus } \\
(M . \text { viscosa })\end{array}$} & $\begin{array}{l}\mathrm{K} 6(=137 / 89-2) ; \mathrm{K} 7(=311 / 89-1) ; \mathrm{K} 9(= \\
427 / 89-1) ; \mathrm{K} 2(=80 / 90-4) ; \mathrm{K} 3(=79 / 90-3) ; \\
\mathrm{K} 23(=407 / 90) ; \mathrm{K} 30(=78 / 90) ; \mathrm{K} 34(= \\
14 / 90) ; \mathrm{K} 38(=21 / 90) ; \mathrm{K} 27(=73 / 91) ; \mathrm{K} 58 \\
(=147 / 92-1) ; \mathrm{F} 70 ; \mathrm{K} 49(=11 / 94-2) ; \mathrm{K} 54 \\
(=65 / 94-4)\end{array}$ & Atlantic salmon & South-west Iceland, $64^{\circ} \mathrm{N}$ \\
\hline & $\mathrm{K} 35(=32 / 90) ; \mathrm{K} 37(=79 / 89-6)$ & Rainbow trout & South-west Iceland, $64^{\circ} \mathrm{N}$ \\
\hline & $\begin{array}{l}\mathrm{K} 11(=451 / 89-1) ; \mathrm{K} 25(=537 / 90-2) ; \mathrm{K} 47 \\
(=136 / 93-1) ; \mathrm{K} 56(=195 / 94-1)\end{array}$ & Atlantic salmon & North Iceland, $66^{\circ} \mathrm{N}$ \\
\hline & F57 & Lumpsucker & South-west Iceland, $64^{\circ} \mathrm{N}$ \\
\hline & $95 / 449(=3039)$ & Atlantic salmon & Norway, $58-59^{\circ} \mathrm{N}$ \\
\hline & $\begin{array}{l}138 / 94 ; 288 / 95(=\mathrm{AL} 266) ; 289 / 95(=\mathrm{AL} 262) \\
290 / 95(=\mathrm{AL} 265) ; 292 / 95(=\mathrm{AL} 267) ; \\
293 / 95 ; 88 / 478^{\mathrm{T}} ; 94 / 1793-2 ; 95 / 371(=2987) \\
95 / 373(=2988) ; 95 / 378(=2991) ; 95 / 403 \\
(=3041) ; 95 / 453(=3040) ; 95 / 461(=3049) \\
95 / 880(=3135)\end{array}$ & Atlantic salmon & Norway, $62-64^{\circ} \mathrm{N}$ \\
\hline & $153 / 94 ; 270 / 95 ; 271 / 95$ & Atlantic salmon & Norway, $67-68^{\circ} \mathrm{N}$ \\
\hline \multirow[t]{7}{*}{ V. wodanis } & $\begin{array}{l}\mathrm{K} 8(=419 / 89-4) ; \mathrm{K} 16(=396 / 90-3) ; \mathrm{K} 26 \\
(=42 / 91) ; \mathrm{K} 29(=78 / 90) ; \mathrm{K} 32(=80 / 90-1) \\
\mathrm{K} 48(=11 / 94-1) ; \mathrm{K} 59(=147 / 92-2)\end{array}$ & Atlantic salmon & South-west Iceland, $64^{\circ} \mathrm{N}$ \\
\hline & $\mathrm{K} 16(=396 / 90-3)$ & Rainbow trout & South-west Iceland, $64^{\circ} \mathrm{N}$ \\
\hline & $\begin{array}{l}\mathrm{K} 4(=312 / 90) ; \mathrm{K} 12(=451 / 89-2) ; \mathrm{K} 13(= \\
525 / 89-3) ; \mathrm{K} 14(=525 / 89-4) ; \mathrm{K} 24(=537 / \\
90-1) ; \mathrm{K} 28(=77 / 90) ; \mathrm{K} 31(=114 / 90-1) ; \mathrm{K} 57 \\
(=195 / 94-2)\end{array}$ & Atlantic salmon & North Iceland, $66^{\circ} \mathrm{N}$ \\
\hline & $\mathrm{F} 31$ & Haddock & South-west Iceland, $64^{\circ} \mathrm{N}$ \\
\hline & $95 / 240$ & Atlantic salmon & Norway, $59-60^{\circ} \mathrm{N}$ \\
\hline & $88 / 441^{\mathrm{T}}$ & Atlantic salmon & Norway, $61-62^{\circ} \mathrm{N}$ \\
\hline & $\begin{array}{l}157-94 ; 287 / 95(=\text { AL } 263) ; 291 / 95(=\text { AL } 264) \\
94 / 1793-1 ; 95 / 313 ; 95 / 325 ; 95 / 326\end{array}$ & Atlantic salmon & Norway, $62-64^{\circ} \mathrm{N}$ \\
\hline
\end{tabular}

$\mathrm{HCl}, 100 \mathrm{mM}$ boric acid, $2 \mathrm{mM}$ EDTA, pH 8.3) was used as the electrophoresis buffer. Gels were run at a constant power of $110 \mathrm{~W}$ for approximately $150 \mathrm{~min}$. After electrophoresis, gels were transferred to $3 \mathrm{MM}$ Whatman chromatography paper and vacuum dried on a gel dryer (model 583; Bio$\mathrm{Rad})$ for $50 \mathrm{~min}$ at $80^{\circ} \mathrm{C}$. A sheet of Hyperfilm-MP (Amersham) was exposed to the dried gel. Exposure times varied between 19 and $24 \mathrm{~h}$, depending on the measured radioactivity of the gel. Films were developed using a Fuji RGII X-ray Film Processor. Autoradiograms were scanned by a RayVen RSU1 densitoscanner (X-Ray Scanner Corporation). Digitized optical densities were saved as TIFF files and further processed using GelCompar 3.1 software (Applied Maths). Digital images were normalized and combined according to the methods described by Vauterin \& Vauterin (1992). A similarity matrix was created using the Dice similarity coefficient, $S_{\mathrm{D}}$ (Sneath \& Sokal, 1973). For band comparison, a band position tolerance value of $0.8 \%$ was allowed to compensate for misalignment of homologous bands due to technical imperfections. The unweighted pair group methods using average linkages (UPGMA) was used to cluster the patterns (Vauterin \& Vauterin, 1992).

SDS-PAGE. Bacterial growth was harvested from one or two Marine agar plates and washed three times in $1 \mathrm{ml}$ phosphate buffer with $2 \% \mathrm{NaCl}, \mathrm{pH} 7 \cdot 3$, while keeping all material on ice. The pellet was resuspended in $0.9 \mathrm{ml} \mathrm{STB}$ buffer consisting of $0.75 \%(\mathrm{w} / \mathrm{v})$ Tris $/ \mathrm{HCl}, 5 \%(\mathrm{v} / \mathrm{v})$ mercaptoethanol and $5 \%(\mathrm{w} / \mathrm{v})$ glycerol to an $\mathrm{OD}_{590}$ of $0 \cdot 8-1 \cdot 1$ and mixed before adding $100 \mu 120 \%$ SDS. The sample was heated at $95^{\circ} \mathrm{C}$ for $10 \mathrm{~min}$, cooled and centrifuged at 10000 r.p.m. for $5 \mathrm{~min}$. The supernatant was kept frozen until used. The samples were run overnight in a $1.5 \mathrm{~mm} 5 \%$ (w/v) acrylamide stacking gel, $\mathrm{pH} 6 \cdot 8$, and a $12 \%$ acrylamide separating gel, $\mathrm{pH} 8 \cdot 8$, at $6 \mathrm{~mA}$ per gel using Hoefer SE600 electrophoresis equipment. After fixation in $3 \%(\mathrm{w} / \mathrm{v}) \mathrm{TCA}$, gels were stained with Coomassie blue, destained and dried. For correction of gel to gel variation, four samples of Psychrobacter immobilis LMG 1125 were run on each gel. The gels were scanned, normalization was performed and clustering of the strains was made by using the UPGMA method with GelCompar software (Vauterin \& Vauterin, 1992).

Biochemical, physiological and serological tests. The ability to utilize four different sugars as sole organic source of carbon with and without $2 \mathrm{mg}$ Casamino acids per $100 \mathrm{ml}$ was tested in a basal medium according to Lee et al. (1981). Bacteriological Peptone L37 (Oxoid) supplemented with synthetic seawater (Colwell \& Morita, 1964) was used for 
testing the minimal amount of peptone required for growth. Nutritional requirements of the strains for growth on amino acids as sole source of carbon and nitrogen were performed in synthetic seawater supplemented with $1 \%$ amino acid and $1.5 \%$ agar as described by Colwell \& Morita (1964). All other biological and serological tests were performed as described previously (Benediktsdóttir et al., 1998). Thermometers used to control temperatures in incubators when testing growth at 21 and $25^{\circ} \mathrm{C}$ were calibrated according to measurement standard no. G50 075 traceable to the International Temperature Standard (ITS-90).

Virulence. Atlantic salmon parr of approximately $10 \mathrm{~g}$, originating from a smolt-producing facility with no known disease history, were transferred to the experimental facility at least $4 \mathrm{~d}$ before challenge. The fish were kept in fresh water at $11{ }^{\circ} \mathrm{C}$. Pathological changes in fish were examined after inoculation with the three strains K56, F57 and 88/478 ${ }^{\mathrm{T}}$, but $\mathrm{LD}_{50}$ was determined for K56 and F57, which were passed serially four times through fish to enhance the virulence. Cultivation of bacteria, determination of viable count and performance of the challenge were carried out as described previously for strain K58 (Benediktsdóttir et al., 1998).

\section{RESULTS}

\section{S rDNA sequence studies}

To determine the relationship of $V$. viscosus and $V$. wodanis to other members of the genus Vibrio the almost complete 16S rRNA sequences were compared to the Vibrio group and the Pseudoalteromonas group within the $\gamma$-proteobacteria (Maidak et al., 1997). A tree constructed from the matrix of sequence similarities (Fig. 1) demonstrates that $V$. viscosus clusters within the Pseudoalteromonas group, whereas $V$. wodanis clusters within the Vibrio fischeri assemblage.

As seen in Table 2, Vibrio viscosus shows the highest $16 \mathrm{~S}$ rRNA gene sequence similarity of $99 \%$ to the sequence of $M$. marina.

$V$. wodanis shows the highest $16 \mathrm{~S}$ rRNA gene sequence similarity of $98.8 \%$ to the sequence of $V$. logei CIP 103204 (NCIMB 1143) and forms a distinct cluster with $V$. logei and Vibrio salmonicida (Fig. 1). Within this cluster $V$. wodanis represents a distinct branch.

\section{AFLP}

Numerical analysis of the AFLP banding patterns allowed the delineation of two main clusters at $40 \%$ similarity. All $V$. viscosus strains $(n=30)$ included in this study grouped together in one cluster and the $V$. wodanis strains, except for K59, formed another cluster (Fig. 2). Reference strains of $M$. marina NCIMB $1144^{\mathrm{T}}, V$. logei NCIMB $2252^{\mathrm{T}}$ and $V$. logei NCIMB 1143 were included, but none of them clustered with the $V$. viscosus or $V$. wodanis strains.

Within the $V$. viscosus strains three subgroups could be distinguished at $75 \%$ relationship. One subgroup contained the isolates originating from Norway, while



Fig. 1. Dendrogram derived from the almost complete $16 \mathrm{~S}$ rRNA sequences of $V$. viscosus ( $M$. viscosa), $V$. wodanis and Vibrio reference strains. The tree was constructed from a distance matrix by using the algorithm of DeSoete (1983). The distance matrix was derived from a similarity matrix (data not shown) by using the correction of Jukes \& Cantor (1969). E. coli was used as the root organism. The numbers are the estimated confidence levels, expressed as percentages, for the positions of the branches, as determined by a bootstrap analysis. Bar, $10 \%$ difference between sequences, as determined by measuring the lengths of the horizontal lines connecting two species.

the isolates from Iceland constituted two subgroups and a single strain. Within each subgroup of $V$. viscosus the isolates shared almost identical banding patterns. All the Norwegian isolates were very homogeneous with AFLP genomic patterns, which are characterized by two or three heavy bands. One of the Icelandic subgroups contained strains isolated from salmonids in south-west Iceland, whereas the other subgroup contained four strains isolated from salmonids in north Iceland. F57, isolated from a healthy lumpsucker and clustered within the $V$. viscosus cluster, was not included in these homogeneous subgroups.

The $V$. wodanis strains made one heterogeneous cluster at $45 \%$ similarity, Icelandic and Norwegian strains clustering side by side. A strain isolated from a healthy haddock off the Icelandic coast and identified as $V$. 
Table 2. Levels of $16 \mathrm{~S}$ rRNA sequence similarity based on a comparison of almost complete $16 \mathrm{~S}$ rRNA sequences between $V$. viscosus ( $M$. viscosa), $V$. wodanis and related Vibrio species

\begin{tabular}{|c|c|c|}
\hline \multirow[t]{2}{*}{ Strain (EMBL accession no.) } & \multicolumn{2}{|c|}{$\begin{array}{l}\text { Percentage 16S rRNA } \\
\text { sequence similarity to: }\end{array}$} \\
\hline & $\begin{array}{l}\text { V. viscosus } \\
(\text { M. viscosa })\end{array}$ & V. wodanis \\
\hline Vibrio viscosus (Moritella viscosa) & - & $90 \cdot 1$ \\
\hline Pseudoalteromonas haloplanktis ATCC $14393^{\mathrm{T}}$ (X67024) & $90 \cdot 4$ & $90 \cdot 1$ \\
\hline Shewanella algae Bry (X81621) & $91 \cdot 5$ & $89 \cdot 1$ \\
\hline Shewanella putrefaciens LMG $2268^{\mathrm{T}}$ (X81623) & $91 \cdot 5$ & $89 \cdot 1$ \\
\hline Shewanella hanedai CIP $103077^{\mathrm{T}}$ (X82132) & $91 \cdot 0$ & $89 \cdot 7$ \\
\hline Shewanella benthica ATCC 43992 (X82131) & $92 \cdot 0$ & $89 \cdot 9$ \\
\hline Moritella marina MP-1 $1^{\mathrm{T}}$, ATCC $15381^{\mathrm{T}}$, NCIMB $1144^{\mathrm{T}}$ & $99 \cdot 0$ & $90 \cdot 7$ \\
\hline Ferrimonas balearica DSM 9799 (X93021) & $90 \cdot 9$ & $89 \cdot 4$ \\
\hline Vibrio wodanis & $90 \cdot 1$ & - \\
\hline $\begin{array}{l}\text { Vibrio orientalis CIP } 102891^{\mathrm{T}} \text {, ATCC } 33934^{\mathrm{T}} \text {, NCIMB } 2195^{\mathrm{T}} \\
(\mathrm{X} 74719)\end{array}$ & $89 \cdot 1$ & $94 \cdot 8$ \\
\hline Vibrio furnissii CIP 102972 ${ }^{\mathrm{T}}$, ATCC $35016^{\mathrm{T}}$ (X74704) & $89 \cdot 9$ & $94 \cdot 9$ \\
\hline Vibrio salmonicida NCIMB $2262^{\mathrm{T}}$ (X70643) & $89 \cdot 6$ & $98 \cdot 5$ \\
\hline Vibrio logei CIP 103204, ATCC 15382, NCIMB 1143 (X74708) & $89 \cdot 8$ & $98 \cdot 8$ \\
\hline Vibrio fischeri NCIMB $1281^{\mathrm{T}}$, ATCC $7744^{\mathrm{T}}$ (X74702) & $90 \cdot 2$ & $98 \cdot 0$ \\
\hline Photobacterium fischeri MJ-1 (Z21729) & $90 \cdot 0$ & $97 \cdot 1$ \\
\hline Vibrio nigripulchritudo CIP $103195^{\mathrm{T}}$, ATCC $27043^{\mathrm{T}}$ (X74717) & $90 \cdot 0$ & $95 \cdot 0$ \\
\hline Vibrio alginolyticus CIP $75.03^{\mathrm{T}}$, ATCC $17749^{\mathrm{T}}$ (X74690) & $89 \cdot 8$ & $95 \cdot 3$ \\
\hline $\begin{array}{l}\text { Vibrio fluvialis NCIMB } 2249^{\mathrm{T}} \text {, ATCC } 33809^{\mathrm{T}} \text {, NCTC } 11327^{\mathrm{T}} \\
\text { (X74703) }\end{array}$ & $89 \cdot 9$ & $94 \cdot 9$ \\
\hline Escherichia coli & $87 \cdot 3$ & $90 \cdot 1$ \\
\hline
\end{tabular}

wodanis by biochemical tests and SDS-PAGE clustered among the $V$. wodanis strains isolated from salmonids.

\section{SDS-PAGE}

Numerical analysis of the SDS-PAGE data of $25 \mathrm{~V}$. viscosus strains isolated from diseased fish showed that the $V$. viscosus strains clustered at $92.8 \%$ similarity, but $23 \mathrm{~V}$. wodanis strains clustered at $88 \cdot 3 \%$ similarity. M. marina NCIMB $1144^{\mathrm{T}}$ showed an $82.5 \%$ relationship with the $V$. viscosus strains, and $V$. logei NCIMB $2252^{\mathrm{T}}$ and $V$. logei NCIMB 1143 showed $84.5 \%$ similarity to the $V$. wodanis cluster (Fig. 3a, b). All $V$. viscosus strains isolated from salmonids in south-west Iceland and in Norway exhibited an identical SDSPAGE protein pattern. Four strains isolated in north Iceland showed a pattern that only differed from the main cluster by one protein band, and a third pattern was shown by the strain isolated from a lumpsucker, F57. The main difference between clusters of $V$. viscosus was the presence of a major band of approximately $32 \mathrm{kDa}$ in strains of the main cluster that was lacking in the strains originating in north Iceland and that instead had a broad, approximately $34 \mathrm{kDa}$ band and, in F57, a broad band of $36 \mathrm{kDa}$. (Fig. 4a).

More strain to strain variability was seen among $V$. wodanis strains, and subclusters that formed within the $V$. wodanis cluster were not dependent on the origin of the strains. The main difference within the $V$. wodanis cluster was the presence or absence of a major protein band between 66 and $90 \mathrm{kDa}$. (Fig. 4b).

\section{Biochemical tests and growth requirements}

Strains of $V$. viscosus and $M$. marina produced acid from glucose, ribose and $N$-acetylglucosamine. They did not produce acid from the following carbohydrates: arabinose, cellobiose, glycerol, inositol, lactose, mannitol, melibiose, rhamnose, salicin, sorbitol, sucrose and trehalose. Salmonid strains of $V$. viscosus originating from south-west Iceland produced acid from mannose and maltose while strains originating from north Iceland and Norway and $M$. marina were negative. All $V$. viscosus strains and $M$. marina were negative in arginine dihydrolase and ornithine decarboxylase production, and all except the four strains isolated in north Iceland produced lysine decarboxylase.

$V$. viscosus and $M$. marina degraded gelatin, DNA, Tween 20 and Tween 80 . V. viscosus strains degraded starch, and $50 \%$ of Norwegian strains and $70 \%$ of 




Fig. 2. Dendrogram and digitized AFLP patterns of $M$. viscosa (V. viscosus) and $V$. wodanis strains and related reference strains.

Icelandic strains of $V$. viscosus were able to degrade chitin.

No $V$. viscosus strain was able to grow at $25^{\circ} \mathrm{C}$, but all grew at 21 and $4^{\circ} \mathrm{C}$. They showed growth on nutrient agar supplemented with 2 and $3 \% \mathrm{NaCl}$, but not on nutrient agar supplemented with 1 or $4 \% \mathrm{NaCl} . M$. marina did not grow at $21{ }^{\circ} \mathrm{C}$ nor on nutrient agar supplemented with $2 \% \mathrm{NaCl}$. Almost all $V$. viscosus strains and $M$. marina utilized glucose and ribose as sole carbon source, but none could utilize trehalose, except when the trehalose medium was supplemented with $0.001 \%$ Casamino acids. All of these were able to grow on media containing $1 \%$ peptone in synthetic seawater, but not when the amount of peptone was reduced to $0.5 \%$. When $1 \% \mathrm{~L}$-proline was used as sole source of carbon and nitrogen, two $V$. viscosus strains could grow but not $M$. marina. No $V$. viscosus strain was able to grow on TCBS medium (Oxoid) and neither did M. marina.

The $V$. viscosus strains and M. marina showed a zone 
(a)

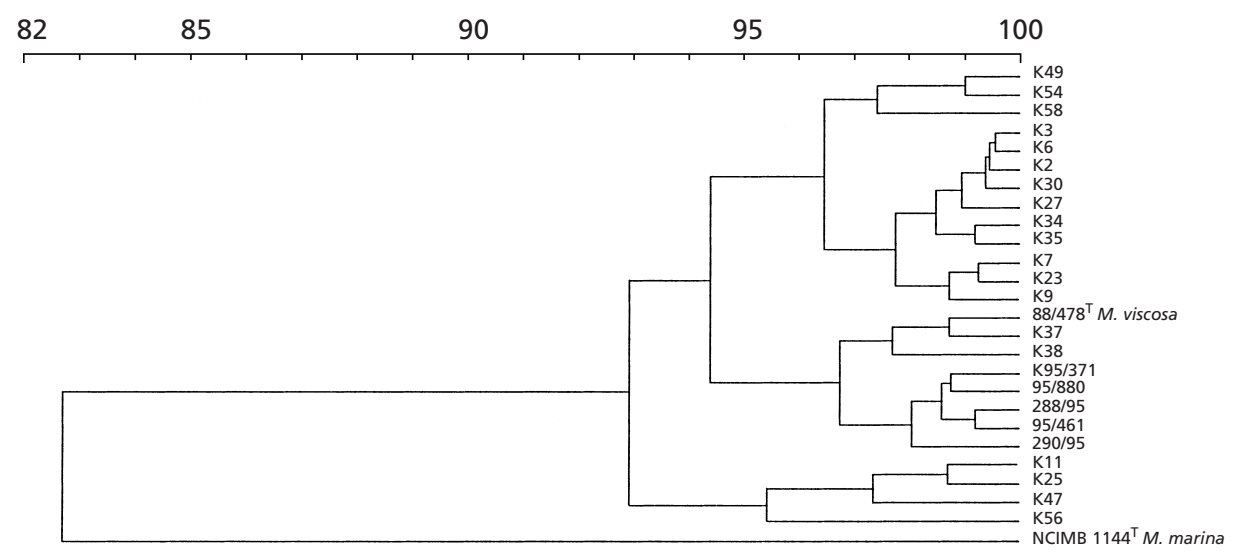

(b)

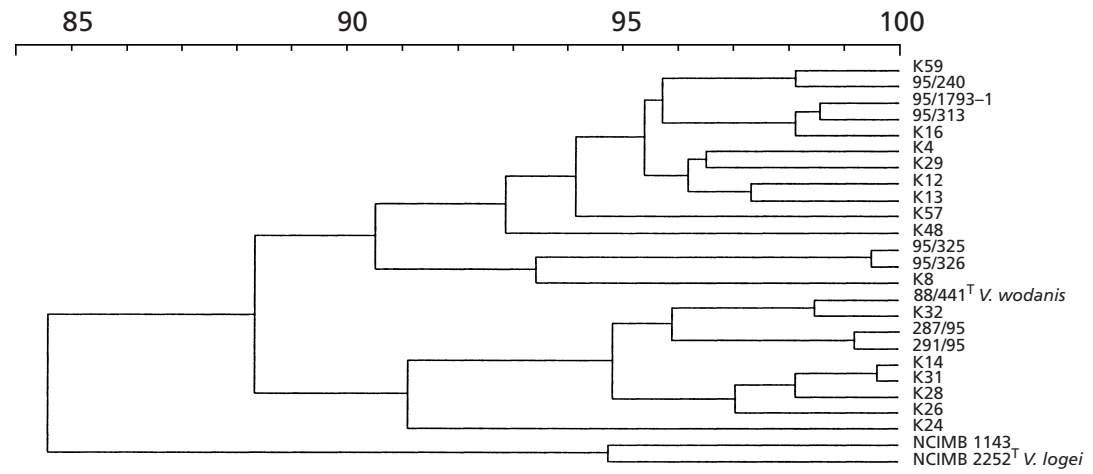

Fig. 3. Dendrogram based on SDS-PAGE protein profiles of whole cells of (a) M. viscosa (V. viscosus) and (b) V. wodanis strains and related reference strains.

of inhibition with $150 \mu \mathrm{g}$ of the vibriostat 0129 but no zone or a very small zone with $10 \mu \mathrm{g}$.

All $V$. viscosus strains isolated from salmonids in both countries agglutinated in sera prepared against $V$. viscosus $\mathrm{K} 2$, but the single strain F57 did not react with the antisera and neither did M. marina.

The $V$. wodanis strains produced acid from glucose, $N$ acetylglucosamine, ribose, glycerol, maltose and trehalose, and $43 \%$ of the strains produced acid from mannitol, $96 \%$ from mannose and $78 \%$ from sucrose. All strains were negative in acid production from arabinose, cellobiose, lactose and sorbitol.

All $V$. wodanis strains utilized glucose, but an overall heterogeneity was observed in the utilization of ribose, trehalose and L-proline. One $V$. wodanis isolate grew at $1 \% \mathrm{NaCl}$, all grew at 2,3 and $4 \%$, and 16 of the $23 \mathrm{~V}$. wodanis isolates grew at $5 \% \mathrm{NaCl}$. All $V$. wodanis strains were able to grow on medium containing $1 \%$ peptone in synthetic seawater, but 21 of $25 \mathrm{~V}$. wodanis strains tested were able to grow on $0.5 \%$ peptone. Only $30 \%$ of the $V$. wodanis strains showed growth on TCBS agar. In none of the tests was grouping of $V$. wodanis according to geographical origin noted, except growth at $25^{\circ} \mathrm{C}: 13$ of $14 \mathrm{~V}$. wodanis strains isolated in Iceland did not grow at $25^{\circ} \mathrm{C}$, while seven of nine $V$. wodanis strains isolated in Norway did.

\section{Challenge tests}

All fish challenged with $1 \cdot 1 \times 10^{3}$ c.f.u. or more of K56 died, as did four of ten fish challenged with $1.1 \times 10^{2}$ c.f.u. All fish challenged with $5 \cdot 5 \times 10^{7}$ c.f.u. of F57 died, and so did nine, one and no fish challenged with $5.5 \times 10^{6}, 5 \cdot 5 \times 10^{5}$ and $5.5 \times 10^{4}$, respectively, with the $\mathrm{LD}_{50}$ calculated to be $1.7 \times 10^{6}$ c.f.u.

\section{Pathology}

The skin colour of affected fish receiving all three strains became darker around the injection site and subsequently turned greyish with necrotic skin and occasionally slight petechial haemorrhaging. Generally there was liquefactive necrosis with a varying degree of haemorrhaging in the underlying muscle. Internal organs, especially the liver of fish receiving strain F57, were frequently pale. Internal lesions of fish receiving strains $88 / 478^{\mathrm{T}}$ and $\mathrm{K} 56$ were characterized 



Fig. 4. SDS-PAGE protein profiles of whole cells. (a) Lanes: 1 and 7 , molecular mass markers; $2, \mathrm{~F} 57 ; 3, \mathrm{~K} 56 ; 4, \mathrm{~K} 58 ; 5, \mathrm{~V}$.


Lanes: 1 and 7 , molecular mass markers; $2, V$. logei NCIMB $2252^{\mathrm{T}}$; 3, V. wodanis NVI 88/441 ${ }^{\top} ; 4,95 / 325 ; 5, \mathrm{~K} 59 ; 6, \mathrm{~K} 32$.

by rather heavy disseminated haemorrhages in the liver, sometimes with diffuse and heavy petechial haemorrhages in the perivisceral fat around the pyloric caeca and frequently with mucosal and submucosal disseminated haemorrhages of the small intestines and the pyloric area. These changes were not seen in fish receiving strain F57.

\section{DISCUSSION}

Molecular characterization by AFLP offers a high degree of discrimination and the results presented here demonstrate its use in epidemiological analysis. The present results of the AFLP analysis indicate a clear correlation between the grouping and the origin of the $V$. viscosus strains: almost identical patterns of strains of $V$. viscosus appeared according to their geographical location of isolation. This indicates a common clonal origin of $V$. viscosus within particular geographical areas (Ørskov \& Ørskov, 1983) and that clones of $V$. viscosus are spread within fish farms and even between farms within a given geographical area.

Strains originating in Iceland grouped into two clusters and a single strain that were more related to each other than to strains originating in Norway, which only clustered into one group. The isolates from Norway that were included in the AFLP analysis originated from 62 to $65^{\circ} \mathrm{N}$, but isolates from other geographical areas or isolates originating from sources other than salmonid fish would probably give another pattern. The differences between the AFLP clusters were reflected by differences in one to three biochemical tests and within each AFLP group strains were biochemically homogeneous. The difference between the two groups isolated in Iceland was detected by SDS-PAGE protein profile analysis, but not the difference between the genetically less related groups of strains of $V$. viscosus originating in Norway and south-west Iceland. The homogeneous results from the SDS-PAGE protein profile analysis make this method well suited for species identification.

Representatives of the two AFLP groups of $V$. viscosus isolated in south-west Iceland and in Norway have been shown to be virulent for salmonid fish (Benediktsdóttir et al., 1998; Lunder et al., 1995). In this study a representative of the AFLP group isolated in north Iceland was shown to be virulent as well and the pathological symptoms were the same. A single strain isolated from the gills of a healthy lumpsucker, was low- or non-virulent, indicating the existence of non-virulent clones of $V$. viscosus in the environment.

Results from AFLP, SDS-PAGE and biochemical tests indicate that $V$. wodanis found in winter ulcers is a defined but heterogeneous species, not showing any sign of clonal spread that is often characteristic of primary pathogens. This result is consistent with challenge tests with these bacteria performed separately in Norway and Iceland that did not indicate any pathogenicity to salmon parr (Lunder et al., 1995; Benediktsdóttir et al., 1998). However, the independent and repeated findings of $V$. wodanis in winter ulcers in Norway, Iceland and Scotland indicate strongly that $V$. wodanis is an important opportunistic 
pathogen that may suppress the healing process of skin by colonizing ulcers of salmon infected primarily with V. viscosus.

$V$. viscosus is rather inert biochemically and often needs prolonged incubation times on test media; in addition it does not grow readily on all test media that support growth of vibrios. In this report we show that for most strains $1 \%$ peptone is needed for growth. This finding includes the fact that $V$. viscosus does not grow in salt-supplemented Hugh and Leifson's OF Medium and other media often used for fermentation tests for vibrios. Faint growth of two strains of $V$. viscosus on TCBS agar was observed and not all strains of $V$. wodanis could grow on TCBS. The growth of $V$. viscosus and of $V$. wodanis in different salt concentrations observed in this study is inconsistent with the results of Lunder et al. (2000) who reported growth of the $V$. viscosus strains in $1-4 \% \mathrm{NaCl}$ and of the $V$. wodanis strains in $0.5-5 \% \mathrm{NaCl}$. They also reported growth of $V$. viscosus strains at $25^{\circ} \mathrm{C}$ that was not observed at this laboratory, with repeated testing both on agar media with and without blood, using an incubator controlled with a calibrated thermometer.

Colwell \& Morita (1964) reported growth of M. marina ATCC $15381^{\mathrm{T}}$ (NCIMB $1144^{\mathrm{T}}$ ) on proline after the first isolation of this species. The strain seems to have lost this property: no growth of M. marina and growth of only two strains of $V$. viscosus was observed using proline as sole source of carbon and nitrogen. However, the invariant results obtained from the utilization tests in this study indicate that these kinds of tests should be used with great caution for M. marina and $V$. viscosus. Both species often render themselves noncultivable after being kept on an agar or broth medium for some time, resulting in possible false negative results.

The sequencing of $16 \mathrm{~S}$ rRNA of $V$. wodanis revealed that this species clusters within the $V$. fischeri assemblage. $V$. fischer $i$ and $V$. loge $i$ are formerly members of the genus Photobacterium (Bang et al., 1978), but were transferred to the genus Vibrio because evolutionary divergence was indicated by amino acid sequencing of the glutamine synthetase and superoxide dismutase enzymes (Baumann \& Baumann, 1980). 16S rRNA sequences indicate that these species, including $V$. wodanis, are more related to each other than to other bacteria of the Vibrio genus, but further studies are needed to determine if they should be transferred to a separate genus.

$V$. viscosus clustered within the Pseudoalteromonas/ Shewanella group and it shared $99 \cdot 1 \%$ similarity to $M$. marina. We therefore propose that Vibrio viscosus should be reclassified and renamed Moritella viscosa comb. nov.

$M$. viscosa has a thymine-thymine insertion between bases 206 and 207 (Escherichia coli numbering), supporting the suggestion of Urakawa et al. (1998) that this is a feature that distinguishes Moritella species from other close taxa.
One barophilic strain included in the study of Urakawa et al. (1998) has been described as a new species, Moritella japonica (Nogi et al., 1998). This strain differs from the $M$. viscosa strains in acid production from glycerol and its total resistance to 0129. $M$. viscosa is the only species of the genus at present that is associated with fish and is virulent. Other strains were isolated from water or sediment at depths from 500 to $8600 \mathrm{~m}$ and at temperatures between 1 and $11^{\circ} \mathrm{C}$ (Urakawa et al., 1998). A common property of Moritella strains is their psychrophily: 15 strains designated MP and described by Colwell \& Morita (1964) as M. marina were all psychrophilic and did not grow at temperatures above $24{ }^{\circ} \mathrm{C}$. Urakawa et al. (1998) reported that the 11 Moritella strains they isolated were psychrophiles.

\section{Description of Moritella viscosa comb. nov.}

Moritella viscosa (vis.co'sa. L. fem. adj. viscosa viscous, because of its thread-forming, adherent colonies).

The description of Moritella viscosa comb. nov. is identical to the description given for Vibrio viscosus by Lunder et al. (2000). In addition, the production of lysine decarboxylase and the production of acid from maltose and mannose are different, depending on subgroups. M. viscosa is partially sensitive to 0129 , showing a very small or no clear zone around a disc containing $10 \mu \mathrm{g} 0129$ and negative for growth on TCBS agar. The type strain is NVI $88 / 478^{\mathrm{T}}$.

\section{ACKNOWLEDGEMENTS}

We thank the Laboratory of Microbiology, University of Ghent, for hosting E. B. for 2 months. We also thank Dirk Dewettinck, Sylvie Van Eygen and Ágústa Thóra Jónsdóttir for excellent technical assistance. This work was supported by the Research Fund of the University of Iceland and the Research Council of Iceland.

\section{REFERENCES}

Arias, C. R., Verdonck, L., Swings, J., Garay, E. \& Aznar, R. (1997). Intraspecific differentation of Vibrio vulnificus biotypes by amplified fragment length polymorphism and ribotyping. Appl Environ Microbiol 63, 2600-2606.

Bang, S. S., Baumann, P. \& Nealson, K. H. (1978). Phenotypic characterization of Photobacterium logei (sp. nov.), a species related to P. fischeri. Curr Microbiol 1, 285-288.

Baumann, L. \& Baumann, P. (1980). Immunological relationships of glutamine synthetases from marine and terrestrial enterobacteria. Curr Microbiol 3, 191-196.

Benediktsdóttir, E., Helgason, S. \& Sigurjónsdóttir, H. (1991). Comparison of forty strains of Vibrio spp. isolated from kidneys of Atlantic salmon, Salmo salar L., with skin lesions. Abstract. In EAFP Conference Handbook: Diseases of Fish and Shellfish, Budapest, p. 125.

Benediktsdóttir, E., Helgason, S. \& Sigurjónsdóttir, H. (1998). Vibrio spp. isolated from salmonids with shallow skin lesions and reared at low temperature. J Fish Dis 21, 19-28.

Bruno, D. W., Griffiths, J., Petrie, J. \& Hastings, T. S. (1998). Vibrio viscosus in farmed Atlantic salmon Salmo salar in Scotland: 
Field and experimental observations. Dis Aquat Org 34, 161-166.

Colwell, R. R. \& Morita, R. Y. (1964). Reisolation and emendation of description of Vibrio marinus (Russell) Ford. J Bacteriol 88 , 831-837.

DeSoete, G. (1983). A least square algorithm for fitting additive trees to proximity data. Psychometrika 48, 621-626.

Gauthier, G., Gauthier, M. \& Christen, R. (1995). Phylogenetic analysis of the genera Alteromonas, Shewanella, and Moritella using genes coding for small-subunit rRNA sequences and division of the genus Alteromonas into two genera, Alteromonas (emended) and Pseudoalteromonas gen. nov., and proposal of twelve new species combinations. Int $J$ Syst Bacteriol 45, 755-761.

Huys, G., Coopman, R., Janssen, P. \& Kersters, K. (1996). Highresolution genotypic analysis of the genus Aeromonas by AFLP fingerprinting. Int J Syst Bacteriol 46, 572-580.

Janssen, P., Coopman, R., Huys, G., Swings, J., Bleeker, M., Vos, P., Zabeau, M. \& Kersters, K. (1996). Evaluation of the DNA fingerprinting method AFLP as a new tool in bacterial taxonomy. Microbiology 142, 1881-1893.

Jukes, T. H. \& Cantor, C. R. (1969). Evolution of protein molecules. In Mammalian Protein Metabolism, vol. 3, pp. 21-132. Edited by H. N. Munro. New York: Academic Press.

Keim, P., Kalif, A., Schupp, J. \& 7 other authors (1997). Molecular evolution and diversity in Bacillus anthracis as detected by amplified fragment length polymorphism markers. $J$ Bacteriol 179, 818-824.

Kersters, K. (1985). Numerical methods in the classification of bacteria by protein electrophoresis. In Computer-Assisted Bacterial Systematics, pp. 337-365. Edited by M. Goodfellow, D. Jones \& F. G. Priest. London: Academic Press.

Kita-Tsukamoto, K., Oyaizu, H., Nanba, K. \& Simidu, U. (1993). Phylogenetic relationships of marine bacteria, mainly members of the family Vibrionaceae, determined on the basis of $16 \mathrm{~S}$ rRNA sequences. Int J Syst Bacteriol 43, 8-19.

Laidler, L. A., Grant, A. N. \& Wadsworth, S. (1999). Preliminary investigations into the bacteriology of skin lesions of Atlantic salmon reared in seawater in Scotland. Fish Vet J 3, 27-31.

Lee, J. V., Shread, P., Furniss, A. L. \& Bryant, T. N. (1981). Taxonomy and description of Vibrio fluvialis sp. nov. (Synonym group F Vibrios, Group EF6). J Appl Bacteriol 50, 73-94.

Lunder, T. (1992). 'Winter ulcer' in Atlantic salmon. A study of pathological changes, transmissibility, and bacterial isolates. DSc thesis, The Norwegian College of Veterinary Medicine, Oslo, Norway.
Lunder, T., Evensen, Ø., Holstad, G. \& Håstein, T. (1995). 'Winter ulcer' in the Atlantic salmon Salmo salar. Pathological and bacteriological investigations and transmission experiments. Dis Aquat Org 23, 39-49.

Lunder, T., Sørum, H., Holstad, G., Steigerwalt, A. G., Mowinckel, P. \& Brenner, D. J. (2000). Phenotypic and genotypic characterization of Vibrio viscosus sp. nov. and Vibrio wodanis sp. nov. isolated from Atlantic salmon (Salmo salar) with 'winter ulcer'. Int J Syst Bacteriol 50, 427-450.

MacDonell, M. T. \& Colwell, R. R. (1985). Phylogeny of the Vibrionaceae, and recommendation for two new genera, Listonella and Shewanella. Syst Appl Microbiol 6, 171-182.

Maidak, B. L., Olsen, G. J., Larsen, N., Overbeek, R., McCaughey, M. J. \& Woese, C. R. (1997). The RDP (Ribosomal Database Project). Nucleic Acids Res 25, 109-110.

Nogi, Y., Kato, C. \& Horikoshi, K. (1998). Moritella japonica sp. nov., a novel barophilic bacterium isolated from a Japan Trench sediment. J Gen Appl Microbiol 44, 289-295.

Ørskov, F. \& Ørskov, I. (1983). Summary of a workshop on the clone concept in the epidemiology, taxonomy, and evolution of the Enterobacteriaceae and other bacteria. J Infect Dis 148, 346-357.

Pitcher, D. G., Saunders, N. A. \& Owen, R. J. (1989). Rapid extraction of bacterial genomic DNA with guanidium thiocyanate. Lett Appl Microbiol 8, 151-156.

Rainey, F. A., Dorsch, M., Morgan, H. W. \& Stackebrandt, E. (1992). 16S rDNA analyses of Spirochaeta thermophila: its phylogenetic position and implications for the systematics of the order Spirochaetales. Syst Appl Microbiol 15, 197-202.

Sneath, P. H. A. \& Sokal, R. R. (1973). Numerical Taxonomy: the Principles and Practice of Numerical Classification. San Francisco: Freeman.

Steven, S. E. (1990). Molecular systematics of Vibrio and Photobacterium. PhD dissertation. University of Maryland, College Park, MD, USA.

Urakawa, H., Kita-Tsukamoto, K., Steven, S. E., Ohwada, K. \& Colwell, R. R. (1998). A proposal to transfer Vibrio marinus (Russell 1891) to a new genus Moritella gen. nov. as Moritella marina comb. nov. FEMS Microbiol Lett 165, 373-378.

Vauterin, L. \& Vauterin, P. (1992). Computer-aided objective comparison of electrophoresis patterns for grouping and identification of microorganisms. Eur Microbiol 1, 37-41.

Vos, P., Hogers, R., Bleeker, M. \& 8 other authors (1995). AFLP: a new technique for DNA fingerprinting. Nucleic Acids Res 23, 4407-4414. 